\title{
Evaluation of Prolidase Activity, Oxidative Stress, and Antioxidant Enzyme Levels in Testicular and Penile Tissues after Human Chorionic Gonadotropin Treatment in Rats by Predicting Infertility and Erectile Dysfunction
}

\author{
Necip Pirinççia ${ }^{a}$ Serkan Yildirim ${ }^{b} \quad$ Abuzer Taş ${ }^{c} \quad$ Yağmur Kuşcu $^{c} \quad$ TunçOzan $^{a}$ \\ Fatih Firdolaş $^{\mathrm{a}}$ Halit Demir ${ }^{\mathrm{d}}$ Ahmet Karakeci $^{\mathrm{a}}$

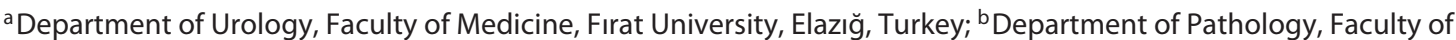 \\ Veterinary Medicine, Atatürk University, Erzurum, Turkey; ${ }^{C}$ Department of Surgery, Faculty of Veterinary Medicine,

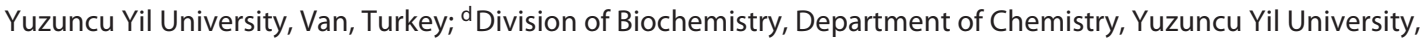 \\ Van, Turkey
}

\section{Significance of the Study}

- This study investigated the effect of human chorionic gonadotropin on prolidase activity, oxidative stress, and antioxidant enzyme levels in testicular and penile tissue in a rat model. We observed that human chorionic gonadotropin negatively affected testicular and penile tissue in rats. Studying the changes in these parameters could provide information on infertility and erectile dysfunction.

\section{Keywords}

Antioxidant · Human chorionic gonadotropin · Oxidative stress · Prolidase

\begin{abstract}
Objectives: Prolidase plays a vital role in collagen turnover, matrix remodeling, and cell growth. We aimed to evaluate the association between treatment with chorionic gonadotropin and infertility and erectile dysfunction by investigating tissue prolidase activity, oxidative stress, and levels of antioxidant enzymes. Materials and Methods: The 16 male Wistar albino rats used in this study were randomly divided into 2 groups: rats treated with human chorionic gonadotropin (hCG) and control rats ( $n=8$ in each group). The rats in
\end{abstract}

\begin{tabular}{ll}
\hline KARGER & $\begin{array}{l}\text { (c) } 2018 \text { The Author(s) } \\
\text { Published by S. Karger AG, Basel }\end{array}$ \\
E-Mail karger@karger.com & $\begin{array}{l}\text { This is an Open Access article licensed under the Creative Commons } \\
\text { Attribution-NonCommercial-4.0 International License (CC BY-NC) } \\
\text { (http://www.karger.com/Services/OpenAccessicense), applicable to } \\
\text { the online version of the article only. Usage and distribution for com- } \\
\text { mercial purposes requires written permission. }\end{array}$
\end{tabular}

the hCG group were subcutaneously injected with 50 IU hCG daily for 15 days, while the rats in the control group were subcutaneously injected isotonic saline. All of the rats were sacrificed by a lethal overdose of sodium pentobarbital at the first month after hCG administration. Prolidase activity and levels of malonyl aldehyde, glutathione reductase, superoxide dismutase (SOD), glutathione peroxidase (GSH-Px), and catalase (CAT) were estimated in the testicular and penile tissue. The testicles and penis were transversely dissected and placed in formalin. Results: Levels of prolidase and malonyl aldehyde in the testicular and penile tissues were significantly higher in the hCG group than in the control group ( $p<0.001$ ), while levels of glutathione reductase, SOD, GSH-Px, and CAT were significantly lower in the hCG group than in the control group ( $p<0.001)$. Conclusions: In this
Abuzer Taş

Department of Surgery, Faculty of Veterinary Medicine, Yuzuncu Yil University Bardakc1 Street

TR-65080 Van (Turkey)

E-Mail abuzertas@ hotmail.com 
study, we observed that treatment with hCG increased prolidase activity and oxidative stress and decreased the antioxidant capacity of penile and testicular tissues; therefore, this may affect fertility and erectile function.

(c) 2018 The Author(s)

Published by S. Karger AG, Basel

\section{Introduction}

Human chorionic gonadotropin (hCG) is a polypeptide hormone produced by the human placenta, with an a subunit that is almost identical to the corresponding a subunits of follicle-stimulating hormone, thyroid-stimulating hormone, and luteinizing hormone, and a mechanism of action similar to that of luteinizing hormone. hCG induces superovulation in females and is used to increase pregnancy rates by enhancing the number of oocytes and embryos, while it is used for the treatment of hypogonadotropic hypogonadism and cryptorchidism in males [1]. Although the use of hCG has beneficial effects like provocation of maturation of the seminiferous epithelium, facilitation of testicular descent and growth, improvement of sperm quality, and regaining of fertility by hypogonadotropic hypogonadism, it may also increase intravascular leucocytes and free oxygen radicals depending on the time of application and the dose, which causes deterioration of spermatogenesis and may lead to infertility [2].

It has been reported that hormonal treatment given for testicular descent may harm germ cells by causing increased apoptotic germ cell death through testicular oxidative stress coupled with the production of reactive oxygen species (ROS) $[3,4]$. ROS are chemical species containing 2 unpaired electrons. They are well known for both their deleterious and beneficial effects. In healthy individuals, ROS are continuously formed at low concentrations as a result of internal reactions and external factors, and some ROS have important physiological functions [5]. Antioxidant defense systems which consist of glutathione reductase, superoxide dismutase (SOD), glutathione peroxidase (GSH-Px), and catalase (CAT) can provide protection from the harmful effects of ROS. Insufficient defense systems may result in severe metabolic malfunctions and oxidative damage to DNA [6].

Prolidase is a member of the matrix metalloproteinase family. It plays a vital role in collagen turnover, matrix remodeling, and cell growth. Increased levels of prolidase seem to be associated with increased levels of nitric oxide and oxidative stress along with decreased levels of anti- oxidant [7]. Also studies on vasculogenic erectile dysfunction have detected higher serum levels of prolidase $[8,9]$. In this study we aimed to examine the effect of hCG on prolidase activity, oxidative stress, and levels of antioxidant enzyme in the testicles and penile tissue in a rat model.

\section{Materials and Methods}

The study protocol was approved by the Animal Research Committee of Yuzuncu Yil University, Van, Turkey (THD-20165116). Six-week-old male Wistar albino rats weighing $250 \pm 50 \mathrm{~g}$ were maintained under standard conditions of a constant temperature of $20-22^{\circ} \mathrm{C}$ and a 12 -h day/night cycle with food and water provided ad libitum. The rats were randomized to the hCG and control groups ( $n=8$ each). The rats in the hCG group were given daily subcutaneous injections of 50 IU of hCG (Pregnyl, Organon) for 15 days as previously described $[10,11]$. Rats in the control group received subcutaneous isotonic saline. All of the rats were sacrificed using a lethal overdose of sodium pentobarbital $(100 \mathrm{mg} / \mathrm{kg}$, administered intraperitoneally) to obtain the normal descending testicular and penile tissue at the first month after administration of hCG.

\section{Biochemical Analysis}

Measurement of Thiobarbituric Acid Reactive Substances

To measure the levels of thiobarbituric acid reactive substances (TBARS), $50 \mathrm{mg}$ of tissue samples were obtained and homogenized in $0.15 \mathrm{~mol} / \mathrm{L} \mathrm{KCl}$. The homogenate was centrifuged at $1,600 \mathrm{~g}$, and the levels of TBARS in the supernatants were determined by the thiobarbituric acid reaction according to the method of Yagi [12]. The method is based on measurement of the absorbance of the pink color produced by the interaction of thiobarbituric acid with TBARS at $530 \mathrm{~nm}$. Values were expressed as milligrams per deciliter.

Measurement of SOD and GSH-Px

The tissues were homogenized in physiological saline ( $1 \mathrm{~g}$ in 5 $\mathrm{mL}$ ) using a homogenizer (B. Braun Melsungen AG, Germany) and centrifuged at 4,000 $\mathrm{g}$ for $20 \mathrm{~min}$ (Heraous Labofur 200, Germany). GSH-Px activity was estimated by measuring the changes in the absorbance of nicotinamide adenine dinucleotide phosphate at $340 \mathrm{~nm}$ and by measuring the decrease in absorbance at $240 \mathrm{~nm}$. SOD activity was measured using the method based on nitroblue tetrazolium reduction rate. One unit of SOD activity was expressed as the amount of enzyme that causes 50\% inhibition in the nitroblue tetrazolium reduction rate [13].

Measurement of CAT Enzyme Activity

Biochemical analysis of tissue CAT activity was performed according to the method described by Sedlak and Lindsay [14]. Supernatants $(0.1 \mathrm{~mL})$ were added to a quartz cuvette containing 2.95 $\mathrm{mL}$ of $19 \mathrm{mmol} / \mathrm{L}$ hydrogen peroxide solution prepared in $0.05 \mathrm{M}$ potassium phosphate buffer ( $\mathrm{pH} 7.00)$. The change in absorbance was monitored at $240 \mathrm{~nm}$ for $5 \mathrm{~min}$ using a spectrophotometer (Shimadzu UV-1201; Japan). 
Table 1. Penile tissue prolidase activity, oxidative stress, and levels of antioxidant enzymes

\begin{tabular}{|c|c|c|c|c|c|}
\hline & \multicolumn{2}{|c|}{ Human chorionic gonadotropin } & \multicolumn{2}{|l|}{ Control } & \multirow[t]{2}{*}{$p$} \\
\hline & mean $\pm S D$ & range & mean $\pm S D$ & range & \\
\hline Prolidase, IU/L & $2.21 \pm 0.23$ & $1.95-2.51$ & $1.08 \pm 0.09$ & $0.99-125$ & 0.001 \\
\hline TBARS, nmol/mL & $110.01 \pm 0.78$ & $108.91-110.88$ & $70.50 \pm 2.01$ & $67.40-72.85$ & 0.001 \\
\hline $\mathrm{GSH}-\mathrm{Rx}, \mathrm{mmol} / \mathrm{g} \mathrm{Hb}$ & $6.63 \pm 0.71$ & $5.67-7.85$ & $13.46 \pm 1.03$ & $12.17-14.83$ & 0.001 \\
\hline $\mathrm{CAT}, \mathrm{u} / \mathrm{mL}$ & $46.52 \pm 3.74$ & $42.07-52.07$ & $67.20 \pm 3.24$ & $62.04-70.56$ & 0.001 \\
\hline $\mathrm{SOD}, \mathrm{IU} / \mathrm{mL}$ & $5.59 \pm 0.61$ & $4.87-6.55$ & $9.95 \pm 0.65$ & $9.03-10.91$ & 0.001 \\
\hline GSH-Px, IU/mL & $57.86 \pm 5.50$ & $49.40-63.01$ & $96.68 \pm 3.83$ & $90.15-100.66$ & 0.001 \\
\hline
\end{tabular}

CAT, catalase; TBARS, thiobarbituric acid reactive substances; SOD, superoxide dismutase; GSH-Px, glutathione peroxidase; GSH-Rx, glutathione reductase; $\mathrm{Hb}$, hemoglobin.

Table 2. Testicular tissue prolidase activity, oxidative stress, and levels of antioxidant enzymes

\begin{tabular}{|c|c|c|c|c|c|}
\hline & \multicolumn{2}{|c|}{ Human chorionic gonadotropin } & \multicolumn{2}{|l|}{ Control } & \multirow[t]{2}{*}{$p$} \\
\hline & mean $\pm S D$ & range & mean $\pm S D$ & range & \\
\hline Prolidase, IU/L & $1.89 \pm 0.35$ & $1.35-2.56$ & $0.90 \pm 0.08$ & $0.80-0.99$ & 0.001 \\
\hline TBARS, nmol/mL & $113.10 \pm 4.95$ & $107.45-119.43$ & $81.23 \pm 5.69$ & $72.12-90.00$ & 0.001 \\
\hline $\mathrm{GSH}-\mathrm{Rx}, \mathrm{mmol} / \mathrm{g} \mathrm{Hb}$ & $11.83 \pm 2.96$ & $7.25-15.27$ & $21.18 \pm 1.93$ & $19.21-25.02$ & 0.001 \\
\hline $\mathrm{CAT}, \mathrm{u} / \mathrm{mL}$ & $57.10 \pm 8.18$ & $44.00-66.29$ & $79.32 \pm 8.64$ & $70.40-97.12$ & 0.001 \\
\hline $\mathrm{SOD}, \mathrm{IU} / \mathrm{mL}$ & $9.63 \pm 1.44$ & $7.44-11.53$ & $11.52 \pm 1.90$ & $8.75-14.20$ & 0.001 \\
\hline GSH-Px, IU/mL & $57.60 \pm 4.44$ & $50.35-63.01$ & $91.45 \pm 10.51$ & $79.03-107.19$ & 0.001 \\
\hline
\end{tabular}

CAT, catalase; TBARS, thiobarbituric acid reactive substances; SOD, superoxide dismutase; GSH-Px, glutathione peroxidase; GSH-Rx, glutathione reductase; Hb, hemoglobin.

Measurement of Prolidase Enzyme Activity

For measurement of the prolidase enzyme activity, a ninhydrin reaction described by Chinard [15] was used. One milliliter of glacial acetic acid and $1 \mathrm{~mL}$ of modified Chinard solution were added to $0.5 \mathrm{~mL}$ of clear supernatant of the tissue homogenate. The mixture was incubated at $90{ }^{\circ} \mathrm{C}$ for $20 \mathrm{~min}$ and then cooled on ice. Then, the absorbance of the samples was measured at $515 \mathrm{~nm}$ using a sample without the substrate as the control. The measured proline concentrations were calculated against a standard proline curve of $5 \mathrm{mg} / \mathrm{dL}$ L-proline. One enzyme activity unit was defined as the amount of proline (in $\mu \mathrm{mol} / \mathrm{L}$ ) formed in the reaction step per minute [16].

\section{Measurement of GSH-Rx Enzyme Activity}

As described previously, $1 \mathrm{~g}$ of tissue sample was homogenized in $5 \mathrm{~mL}$ of physiological saline using a homogenizer and then centrifuged at 4,000 $\mathrm{g}$ for $20 \mathrm{~min}$. GSH-Rx activity was measured by observing the changes in the absorbance of nicotinamide adenine dinucleotide phosphate at $340 \mathrm{~nm}$ and by measuring the decrease in absorbance at $240 \mathrm{~nm}$.

Antioxidant Levels after hCG Treatment

in Testicular and Penile Tissues

\section{Statistical Analysis}

Descriptive statistics for the studied characteristics were presented as medians, means, SD, and ranges. Group comparisons were performed using the Mann-Whitney $U$ test. The SPSS (version 13) statistical program was used for all statistical computations.

\section{Results}

While the prolidase and TBARS levels in penile tissue were significantly higher in the hCG group than in the control group, levels of glutathione reductase, SOD, GSH-Px, and CAT were significantly lower in the hCG group than in the control group ( $p<0.05$; Table 1$)$.

Levels of prolidase and TBARS were significantly higher in the testicular tissue of the hCG group than in the control group. The levels of glutathione reductase, GSH-Px, SOD, and CAT were significantly lower in the 
testicular tissues of the hCG group than in those of the control group ( $p<0.05$; Table 2$)$. TBARS, a sign of oxidative stress, is negatively correlated with levels of antioxidant enzymes.

\section{Discussion}

Prolidase is a cytosolic enzyme necessary for specific splitting of imidodipeptides with proline or hydroxyproline at their C-terminals, and it has a major role in collagen turnover and cell growth $[9,17]$. The relationship between collagen and prolidase activity was observed in a study on fibrotic processes, where an increase in prolidase activity was found to be accompanied by an increase in deposition of tissue collagen [17]. The negative effect of free radicals is mediated by degradative agents such as proteolytic enzymes, and the final step of collagen degradation is mediated by prolidase [18].

Prolidase is a specific peptidase that has an important function in human tissues and cells. Prolidase activity has been shown in plasma erythrocytes, leucocytes, and fibroblasts and in organs like the kidney, the brain, the heart, the liver, the small intestines, the stomach, the lung, the spleen, the thymus, and the uterus [19]. While a higher prolidase activity is observed in patients with osteoporosis, osteoarthritis, hypertension, coronary artery disease, and erectile dysfunction $[8,9,17,18,20,21]$, a lower level is observed in renal insufficiency because the main source of prolidase is the kidney [19]. The severity of the antioxidant stress is directly correlated with the inhibition of collagen production in which prolidase is the main enzyme [19]. Tissue prolidase activity may be an indicator of tissue fibrosis [9]. Fibrosis in the testicular and penile tissues may affect the fertility and erectile capacity. Thus, tissue prolidase activity may be an indicator of fertility and erectile capacity. Savas et al. [9] reported that serum prolidase activity is closely associated with vasculogenic erectile dysfunction and its severity, and thus an increase in serum prolidase may be an independing predictive factor for erectile dysfunction.

The use of hCG is reported to have noxious effects which can lead to male infertility due to impaired spermatogenesis because of an increase in free oxygen radicals $[2,22]$. To the best of our knowledge, no other studies in the literature have studied the effects of hCG treatment on prolidase activity, oxidative stress, and antioxidant enzyme levels in the testes and penile tissue. In our study, we found that prolidase activity in the penile and testicular tissues was significantly higher in the hCG group than in the control group. The results do not directly or necessarily apply to treatment in humans.

The body's defense cells may also be important mediators of oxidative stress by the release of important enzymes related to immune reactions. Antioxidant enzymes are responsible for inhibiting oxidative stress. SOD and CAT serve as the primary line of defense in the detoxification of free radicals. Finally, one of the major toxic effects of excessive ROS is damage to the cell membrane via lipid peroxidation, which can be monitored by measuring the levels of TBARS. If the detoxification and neutralization of ROS are insufficient or if excess production of ROS occurs, this will lead to oxidative stress, which represents an imbalance between the level of free radicals and antioxidant defenses [23].

Because developmental parameters in rats are similar to those in humans, histologic evaluation of the rat testis is considered useful. Kaya et al. [24] reported that hCG decreased the number of testicular germinal cells. Another study showed that the effect of hCG is dose dependent and reversible [11]. The negative effect of hCG on Leydig cells is mainly related to oxidative stress and apoptosis [22]. The amount of collagen in penile tissue was shown to be higher in the hCG-treated rats, while the diameters of cavernosal sinus lumens and the diameter of the penis were lower than in the hCG group [25]. In these studies, the effect of hCG on testicular and penile tissue was studied histopathologically, while we studied the effects of hCG by analyzing biochemical parameters.

Treatment with hCG raises testicular levels of hydrogen peroxide along with an increase in lipid peroxidation and a concomitant decrease in enzymatic antioxidant activities like SOD, CAT, and glutathione-transferase. Gautam et al. [2] reported an increase in apoptosis in testicular germ cells and associated this with high oxidative stress and $\mathrm{H}_{2} \mathrm{O}_{2}$ which is a sign of low antioxidant activity. Ozbek et al. [26] found a significant increase in the number of giant cells and degenerated and desquamated cells in a testicular ischemia/reperfusion injury model. Additionally, levels of TBARS were significantly higher, while levels of SOD, CAT, GPX, and reduced glutathione (GSH) were significantly lower. As shown in previous studies, both apoptosis and oxidative stress induce smooth muscle cell and endothelial cell damage in the corpus cavernosum [27]. Oxidative stress increases the tissue levels of TBARS, which is the end product of lipid peroxidation. Atilgan et al. [28] reported that the collagen density in cavernosal tissue increased after oxidative injury induced by bilateral cavernous nerve injury, which may lead to the development of fibrosis in cavernosal tissues. They also used tissue
Pirinççi/Yildirim/Taş/Kuşcu/Ozan/ Fırdolaş/Demir/Karakeci 
levels of TBARS as an indicator of oxidative stress. Yu et al. [29] studied SOD activity and levels of TBARS as a measure of oxidative stress in the corpus cavernosum. SOD is a major cellular defense against the superoxide and TBARS is a reactive aldehyde and one of the many reactive electrophile species that can cause the toxic stress in cells. Yu et al. [29] found that levels of SOD decreased but levels of TBARS increased in diabetes-induced erectile dysfunction. In our study, based on the relatively high TBARS levels and the low levels of antioxidants in the hCG-treated group, we concluded that hCG can negatively impact penile and testicular tissue.

One limitation of this study is that the collagen content was not estimated for fibrosis. The other is that the conver- sion of the therapeutic human dose of hCG into an experimental dose in rats has not been standardized, although many studies in the literature have applied $50 \mathrm{IU} / \mathrm{kg}$.

\section{Conclusion}

In this study, tissue prolidase and levels of TBARS were higher and levels of SOD, GSH-Px, and CAT were lower in hCG-treated rats than in control rats. hCG negatively affected testicular and penile tissues. These observations may contribute to a better understanding of infertility and erectile dysfunction.

\section{References}

1 Sun-Ji Park, Tae-Shin Kim, Jin-Man Kim, et al: Repeated superovulation via PMSG/Hcg administration induces 2-Cys peroxiredoxins expression and overoxidation in the reproductive tracts of female mice. Mol Cells 2015; 38:1071-1078.

2 Gautam DK, Misro MM, Chaki SP, et al: hCG treatment raises $\mathrm{H}_{2} \mathrm{O}_{2}$ levels and induces germ cell apoptosis in rat testis. Apoptosis 2007;12:1173-1182.

3 Emmerson KS, Phang JM: Hydrolysis of proline dipeptides completely fulfills the proline requirement in a proline \pm auxotropic Chinese hamster ovary cell line. J Nutr 1993;123: 909-914.

4 Durak I, Canbolat O, Kavutcu M, et al: Activities of total, cytoplasmic, and mitochondrial superoxide dismutase enzymes in sera and pleural fluids from patients with lung cancer. J Clin Lab Anal 1996;10:17-20.

5 Loft S, Poulsen HE: Cancer risk and oxidative DNA damage in man. J Mol Med 1996;74: 297-312.

6 Valko M, Leibfritz D, Moncol J, et al: Free radicals and antioxidants in normal physiological functions and human disease. Int J Biochem Cell Biol 2007;39:44-84.

7 Pirincci N, Kaba M, Gecit I, et al: Serum prolidase activity, oxidative stress, and antioxidant enzyme levels in patients with renal cell carcinoma. Toxicol Ind Health 2016;32:193199.

8 Savas M, Yeni E, Verit A, et al: Acute effect of phosphodiesterase type 5 inhibitor on serum oxidative status and prolidase activities in men with erectile dysfunction. Clinics (Sao Paulo) 2010;65:1311-1314.

-9 Savas M, Yeni E, Celik H, et al: The association of serum prolidase activity and erectile dysfunction. J Androl 2010;31:146-154.
10 Yilmaz O, Akyol İ, Özyurt M, et al: The influence of hormonal treatment with beta-human chorionic gonadotropin for cryptorchidism on future fertility in rats. J Pediatr Urol 2015; 11:92.e1-e4.

11 Karaman IM, Kaya C, Ozturk M, et al: The effects of human chorionic gonadotrophin on normal testicular tissue of rats: dose-dependence and reversibility. BJU Int 2006;97: 1116-1118.

12 Yagi K: Lipid peroxides and related radicals in clinical medicine; in Armstrong D (ed): Free Radicals in Diagnostic Medicine. New York, Plenum, 1994, pp 1-15.

13 Durak I, Canbolat O, Kavutcu M, et al: Activities of total, cytoplasmic, and mitochondrial superoxide dismutase enzymes in sera and pleural fluids from patients with lung cancer. J Clin Lab Anal 1996;10:17-20.

14 Sedlak J, Lindsay RHC: Estimation of total, protein bound and non-protein sulfhydryl groups in tissue with Ellmann's reagent. Anal Biochem 1968;25:192-205.

15 Chinard P: Photometric determination of proline and ornithine. J Biol Chem 1952;199: 61-65.

16 Trol W, Lindsley J: Aphotometric method for the determination of proline. J Biol Chem 1955;215:655-660.

17 Demirbag R, Yildiz A, Gur M, et al: Serum prolidase activity in patients with hypertension and its relation with left ventricular hypertrophy. Clin Biochem 2007;40:1020-1025.

18 Altindag O, Erel O, Aksoy N, et al: Increased oxidative stress and its relation with collagen metabolism in knee osteoarthritis. Rheumatol Int 2007;27:339-344.

19 Liu G, Nakayama K, Awata S, et al: Prolidase isoenzymes in the rat: their organ distribution, developmental change and specific inhibitors. Pediatr Res 2007;62:54-59.
20 Erbagci AB, Araz M, Erbagci A, et al: Serum prolidase activity as a marker of osteoporosis in type 2 diabetes mellitus. Clin Biochem 2002;35:263-268.

21 Yildiz A, Demirbag R, Yilmaz R, et al: The association of serum prolidase activity with the presence and severity of coronary artery disease. Coron Artery Dis 2008;19:319-325.

-22 Aggarwal A, Misro MM, Maheshwari A, et al: Adverse effects associated with persistent stimulation of Leydig cells with hCG in vitro. Mol Reprod Dev 2009; 76:1076-1083.

23 Houghton PJ, Hylands PJ, Mensah AY, et al: In vitro tests and ethnopharmacological investigations: wound healing as an example. J Ethnopharmacol 2005;100:100-107.

24 Kaya C, Karaman MI, Pirincci N, et al: Human chorionic gonadotropin deteriorates the histology of rat testes. Urol Int 2006;76:274-277.

25 Pirincci N, Yildirim S, Tas A, et al: Histopathological changes that occur on the testicular and penile tissues depending on the treatment of human chorionic gonadotropin: rat model. West Ind Med J DOI: 10.7727/wimj.2015.282.

26 Ozbek O, Altıntas R, Polat A, et al: The protective effect of apocynin on testicular ischemia-reperfusion injury. J Urol 2015;193: 1417-1422.

27 Li XX, Qiu XF, Yu W, et al: Mechanisms of oxidative stress-induced damage and its protection in cavernous mitochondria of diabetic rats. Beijing Da Xue Xue Bao 2011;43:189-193.

28 Atilgan D, Parlaktas BS, Uluocak N, et al: The effects of trimetazidine and sildenafil on bilateral cavernosal nerve injury induced oxidative damage and cavernosal fibrosis in rats. Sci World J 2014;2014:970363.

29 Yu W, Wan Z, Qiu XF, et al: Resveratrol, an activator of SIRT1, restores erectile function in streptozotocin-induced diabetic rats. Asian J Androl 2013;15:646-651. 